\title{
Job Security and Organizational Citizenship Behaviour in Telecommunication Companies in Port Harcourt
}

\author{
${ }^{1}$ Kingsley I. Amadi PhD and ${ }^{2}$ Jonah Charles Tambari PhD \\ ${ }^{1}$ Department of Management, Faculty of Management Sciences, Rivers State University, Nkpolu- \\ Oroworukwo, PMB 5080, Port Harcourt, Nigeria. \\ ${ }^{2}$ Department of Management, Faculty of Management Sciences, University of Port Harcourt, Choba, Rivers
} State, Nigeria

\begin{abstract}
This study sought to examine the relationship between job security and organizational citizenship behaviour in telecommunication companies in Port Harcourt. The study adopted a cross-sectional survey research design in its investigation of the variables. Primary data was generated through structured questionnaire. The population of the study was 134 employees drawn from 4 telecommunication companies in Port Harcourt. The sample size was 100 determined through the Taro Yamen formula for sample size determination and the simple random technique was used. After data cleaning, only data of 91 respondents were finally used for data analysis. The reliability of the research instrument was achieved using the Cronbach's Alpha Coefficient. Spearman Rank Order Correlation Coefficient was used to test the hypotheses with the aid of Statistical Package for the Social Sciences. The study findings revealed that there is a significant relationship between job security and organizational citizenship behaviour in telecommunication companies in Port Harcourt. Thus the study concludes that job security significantly relate with organizational citizenship behaviour in telecommunication companies in Port Harcourt. The study recommends that that employees who are hard working with the firms should be identified and rewarded for their hard work. Components of job security should be factored into telecommunication companies' job description as it will go a long way in sustaining confidence in the course of discharging their duties. However, this study was able to assess quality of work life and employee turnover and measures by which it can be minimized.
\end{abstract}

Keywords: Job Security, Organizational Citizenship Behaviour, Civic Virtue, Conscientiousness and Courtesy

\section{Introduction}

Organizational Citizenship Behaviour (OCB) is conceptualized as positive behavior and willingness to exert energy for success of the organization. Organizations have long been interested in the role of management on how employees think and feel about their jobs, as well as what employees are willing to dedicate to the organization (Dorothea, 2013). Miller (2002) agreed that a person who engaged in OCB might receive appreciation and recognition that includes positive emotion and a greater likelihood of repeating the OCB. According to Organ, Podsakoff and MacKenzie (2006), OCB is known to influence organizational effectiveness, because they enhance co-worker and managerial productivity, adapts to environmental changes, improves organizations' ability to attract and retain the best people and obtain stability of organizational performance and organizational effectiveness by creating social capital. Organizational citizenship behavior (OCB) plays very important role for the better functioning of any organization, defined as behavior that (a) is something extra beyond the basic job description, (b) is without any compensation, and (c) is for the betterment to the organization' Lambert (2006). Organizational Citizenship Behavior (OCB) has been identified by the researchers having considerable financial, nonfinancial, short-term, and long-term outcomes that lead to organizational efficiency and effectiveness (Andaleeb, Shahjehan, Zeb \& Saifullah, 2011). 
In competitive business environment organization need workers who can freely give up their time and energy in order to complete a given task. Though there are seen and unforeseen situations that might occur in the course of achieving such task, most employees still put their best, however, such employees are rarely found. Thus, the behavior portrayed by such employee is known as organizational citizenship behaviour (). This behaviour could be facilitated by how the employee perceive the security of their job. High levels of job security can create substantial benefits to organizations and employees (Stynen Forrier, Sels \& De Witte, 2013; Vuuren, Jong \& Smulders, 2020). However, low levels of job security have become a sizeable social phenomenon, caused by fundamental changes in the economic system of China, such as increase in contractor, technological innovations, and economic downturn (Jiang, Hub, Näswallc, López Bohle \& Wang 2020). For example, previous research demonstrated that the use of contingent workers threatened permanent employees' job security because permanent employees may attribute the use of temporary workers to management intentions to change internal structures (Kraimer, Wayne, Liden \& Sparrowe, 2005). The purpose of this study was to examine the relationship between job security and organizational citizenship behaviour in telecommunication companies in Rivers State.

Furthermore, this study was also guided by the following research questions:

I. What is the relationship between job security and civic virtue in telecommunication companies in Port Harcourt?

II. What is the relationship between job security and conscientiousness in telecommunication companies in Port Harcourt?

III. What is the relationship between job security and courtesy in telecommunication companies in Port Harcourt?

\begin{tabular}{|l|l|}
\hline Job Security & $\begin{array}{c}\text { Organizational } \\
\text { Citizenship Behaviour }\end{array}$ \\
\hline
\end{tabular}

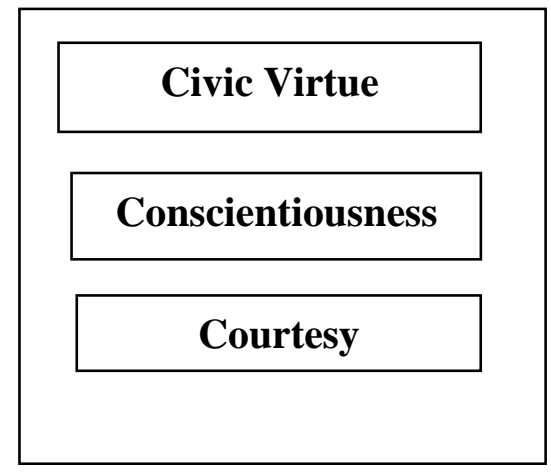

Fig.1 Conceptual Framework for the relationship between job security and organizational citizenship behaviour

Source: Desk Research (2021)

\section{Literature Review}

Theoretical Foundation

\section{Organizational Support Theory}

Research on perceived organizational support began with the observation that if managers are concerned with their employees' commitment to the organization, employees are focused on the organization's commitment to them. For employees, the organization serves as an important source of socio-emotional resources, such as respect and caring, and tangible benefits, such as wages and medical benefits. Being regarded highly by the organization it helps to meet employees' needs for approval, esteem, and affiliation. Positive valuation by the organization also provides an indication that increased effort was noted and rewarded. Employees, therefore, take an active interest in the regard with which they are held by their employer. 
Organizational support theory holds that in order to meet socio-emotional needs and to assess the benefits of increased work effort, employees form a general perception concerning the extent to which the organization values their contributions and cares about their well-being (Eisenberger, Stinglhamber, Vandenberghe, Sucharski \& Rhoades, 2002). Such perceived organizational support (POS) would increase employees' felt obligation to help the organization reach its objectives, their affective commitment to the organization, and their expectation that improved performance would be rewarded. Behavioral outcomes of POS would include increases in role and extra-role performance and decreases in stress and withdrawal behaviors such as absenteeism and turnover. Although there were relatively few studies of POS until the mid-1990, research on the topic has burgeoned in the last few years. Rhoades and Eisenberger's (2002) meta-analysis covered some 70 POS studies carried out through 1999, and over 250 studies have been performed since. The metaanalysis found clear and consistent relationships of POS with its predicted antecedents and consequences.

For an organization to prosper in all its ventures then their employees must behave as good citizens by engaging in positive behaviors (Organ, Podsakoff \& Mackenzie, 2006). Generally speaking, these citizenship behaviors are aimed at supporting both the social and psychological environment of any organization and they determine the success of any organization (Bolino, 2004). Organizational citizenship behavior can maximize on the efficiency and productivity of both the employees and the organization which will ultimately contribute to the effective functioning of an organization. Employees who exhibit citizenship behavior can be described as good soldiers or good citizens of that organization. When employees are treated with kindness and given favorable treatment they will reciprocate by exhibiting citizenship behavior (Smith et al, 2008).

Organizational citizenship has a positive impact on organization and its members and it helps the managers to be able to create a cooperative environment that can increase effectiveness of employees (Podsakoff, 2006). There are many factors that contribute to the determination of organizational citizenship behavior (OCBs), which include altruism, conscientiousness, civic virtue, sportsmanship and courtesy (Organ et. al., 2006). Organizational citizenship behavior was predicted by the work environment. Organizational citizenship behaviors are voluntary and supervisors cannot demand or force their subordinate to perform them. Similarly, the employees do not expect any formal reward (Blau, 2006). The perception of organizational citizenship behavior makes an individual look like a good citizen as well as facilitating him to achieving personal goals (Hui, Lam \& Law, 2009). Keskes (2014) citing Meyer and Allen's (1991) refers to employee's emotional attachment as to the identification with, and involvement in the organization. These definitions view organizational commitment as involving some form of psychological bond between the employees and the organization. The resulting outcomes are increased work performance, reduced absenteeism and reduced turnover (Keskes, 2014).

\section{Job Security}

Job security is the assurance of continuity in one's job in his or her present organization. Just as jobs are increasingly becoming harder and harder to come by, employees are seeking for security and stability of their jobs in their present employment (Evren, 2003). Evren, further states that employee's job security is currently even more relevant in economies where jobs are being slashed and hiring new employees has slowed down due to the weak economy. Bull (2005) postulates that many people experience satisfactions when they belief that the future of their job is good and secured. Job security refers to one's expectation about continuity in a job situation (Akpan, 2013). Singh and Jain (2013) define job security as an employee's assurance or confidence that employees will keep their current job. Similarly, Clark and PostelVinay (2009); Erlinghagen (2008) refer to job security as a situation where employees perceive the continuance of their employment not to be under any threat. This suggests that, employees will be more comfortable and satisfied when there is no threat of dismissal or lay off of their job in their workplace.

Job security according to Pearce and Mawsons (2009) is a mind state in which the employee sees his job stability with the firm in the near future. It is the result of the firm's own practices and policies with the employee which make them more secure or insecure towards the job. Employment security as a term is often used interchangeably with work security and job security, job security is the security of a continued employment in the same occupation with the same employer. Conceptually, work security and employment 
security are broader concepts, including, among other things: self-employment, employment security, the confidence of being able to keep, find or create gainful employment, now and in the future, based on the development of your own human capital and in well-functioning institutions.(Dekker, 2010). Job security plays an important role in both social and working life because it help individuals not to worry about their future, and it contributes to maintaining labor peace, increasing organizations productivity and protecting social balance and values for this employee should not be dismissed from his organization without reasonable grounds, because job security has political and social dimensions (Senol, 2011).

Furthermore, job insecurity refers to the worry and anxiety experienced by an employee in relation to the continuation of the present job (Sverke \& Hellgren, 2002). The burden of worry and anxiety about job threats provoke employees and decreases job satisfaction which ultimately represent distractions that negatively affect performance and organizational productivity (Greenhalgh \& Rossenblatt, 1984). Thus, Jandaghi, Mokhles and Bahrami, 2011) conclude that job insecurity reduces job satisfaction of employees in the work place. Generally, job security is positively associated with job satisfaction. A considerable amount of studies showed that job security is related to employees' job satisfaction (Khan, Nawaz, Aleem \& Hamed, 2012; SHRM, 2003). These findings are supported by Abdullah and Ramay (2012) who in their study reported a positive relationship between job security and job satisfaction of employees. This certifies that job security induces employee satisfaction in any work situation. According to an industrial and organizational psychologists Thomas, Tam and Ohara, (2006) job security is one of the creators of job satisfaction and work related attitudes.

Nazirul, Syeda and Zuby (2014) argue that job security is one of the major components of job satisfaction in any work place because of its relationship with work behaviours. When a job is not secured an employee tends to look for opportunity elsewhere and that makes him /her less committed and when he/she gets the opportunity, he/she quits easily for a better organization. They also went on to say that employees with a high level of job security have a low probability of losing their job in the near future subsequently becomes a source of employees' job satisfaction. On the contrary, Guest (2004) in his study maintains that low job security and working conditions have adverse effect on employee job satisfaction. However, Abdullah and Ramay (2012) stress that secured job is an employee's requirement and wish. Hence, job insecurity tends to affect workers negatively in their organization (Akpan, 2013). Accordingly, Tannenbaum (1992) reports that developing economies have dare need for job security as a top priority in their work place as it increases employees' job satisfaction and loyalty.

\section{Organizational Citizenship Behaviour}

Every employee is expected to perform certain duties or tasks according to job specification, terms of employment and supervisors expectations. However, some individuals perform certain duties far beyond the expected outputs (Okediji, Esin, Sanni \& Umoh, 2009). Some deliberately contribute to the progress and efficiency of the organization, while others go out of their way to motivate and assist their colleagues to complete their assigned tasks. These extra role behaviours beyond the call of duty do not attract any personal benefits and are not provided for in the organization's reward system (Onyishi, 2007). Such extra role behaviour is described as Organizational citizenship behaviour (Organizational Citizenship Behaviour).

Organ (1988) defined Organizational Citizenship Behaviour as Individuals' behaviour that is discretionary, not directly or explicitly recognized by the formal reward system, and in the aggregate promotes the efficient and effective functioning of the organization. He explains further that engagement in Organizational Citizenship Behaviour is generally a personal choice, and omission is not generally seen as punishable (Uhiara, Njoku, Ngozi \& Jimogu, 2011).

\section{Measures of Organizational Citizenship Behaviour \\ Civic Virtue}

Civic virtue is defined as the behavior which exhibits how well a person represents an organization with which they are associated, and how well that person supports their organization outside of an official capacity. According to Borman et al., (2001) civic virtue is to involve oneself responsibly in and of being concerned about the life of the company. Civic virtue is behaviour which exhibits how well a person represents an organization with which they are associated, and how well that person supports their 
organization outside of an official capacity. For example, how well someone represents their business and how they may support that business are all examples of someone's civic virtue.

When an employee is concerned about the life of the organization, shows interest, gets involved in activities, keeps up to date with happenings and generally stands up to defend the policies and practices of the organization, such employee is said to exhibit Civic Virtue (Organ, Podsakoff \& Mackenzie, 2006). It is the commitment to the organization. This also includes exhibiting a behaviour that reflects a person's recognition of the fact that he is an integral part of the organization, such as engaging in the governance of the organization, attending its meetings, getting involved in debates and expressing opinion about the administration of the organization.

\section{Conscientiousness}

Conscientiousness refers to a personality trait of being obedient, dutiful and self-disciplined. At the workplace, it may refer to an employee who is efficient and diligent. A person is said to be conscientious when he is efficient and organized. According to Redman \& Snape (2005), conscientiousness is a discretionary behaviour that goes beyond the basic requirements of the job in terms of obeying work rules, attendance and job performance. This is contrary to a person who is disorderly and irrational or who pretends to be dutiful when he is under supervision. Conscientiousness may be an important predictor of workplace behaviours because it provides the organization and direction that are necessary to produce targeted behaviours (Gore, Kiefner, \& Combs, 2012). Conscientious persons are likely to be thorough and articulate. More conscientious employees will stay informed with up-to-date knowledge about products or services offered (DeYoung, \& Peterson, 2007). They are mostly conformists, compulsive and goal-oriented in their behaviour. It is a discretionary behavior that goes beyond the basic requirements of the job in terms of obeying work rules, attendance and job performance (Redman \& Snape, 2005). OCB impacts work group efficiency during times of crisis management. For 51 example, having conscientiousness and helping others result in decreased inter-group conflict and allow managers to focus on more pressing matters (MacKenzie et al., 2009).

\section{Courtesy}

Courtesy is defined as discretionary behaviors that aim at preventing work-related conflicts with others (Law et al., 2005). This dimension is a form of helping behavior, but one that works to prevent problems from arising. It is a behavior which is polite and considerate towards other people. Courtesy outside of a workplace setting includes behavior such as asking how someone's morning has been or asking after the welfare of a neighbour's child. In a business context, courtesy is usually exhibited through behaviors such as inquiring about personal subjects that a co-worker has previously brought up, asking if a co-worker is having any trouble with a certain work related project, and informing coworkers about prior commitments or any other problems that might cause them to reduce their workload or be absent from work.

Courtesy not only encourages positive social interactions between employees, which improve the work environment, but they can reduce any potential stress that might occur from employees who do not have the courtesy to inform their coworkers about issues such as upcoming absences from work-and so on. It refers to the gestures that help others to prevent interpersonal problems from occurring, such as giving prior notice of the work schedule to someone who is in need, consulting others before taking any actions that would affect them (Organ, 1990). Courtesy or gestures are demonstrated in the interest of preventing creations of problems for co-workers (Organ, 1997). For example, leaving the copier or printer in good condition for other workers' use is an example of courtesy at work (Organ, Podsakoff, \& MacKenzie, 2006).

\section{Job Security and Organizational Citizenship Behaviour}

According to the social exchange theory, the norm of reciprocity indicates that when organizations treat employees in a positive manner, employees should respond favorably by engaging in positive behaviors, such as OCBs (Lam, Liang Ashford \& Lee, 2015). Thus, in our research, we assumed that job security is positively related with OCB. Employees usually consider a secured employment as part of their implied contract with the employer, and expect that the organization will reciprocate by offering them rewards in terms of job security when they work hard (Piccoli, De Witte \& Reisel, 2017). Whereas, employees under the threat of a job loss may perceive the unbalanced exchange relationship between their investment and outcomes they received, which would weaken their motivation to reciprocate the organization in terms of 
OCBs. The imbalanced exchange relationship resulting from a low job security damages the reciprocity principle of social exchange theory, and employees may restore the balance of the exchange relationship with the organization by reducing their OCBs. However, employees with a high job security tend to view it as a benefit from the organization; they are more likely to establish trust and mutual care relationships with the organization, thus, performing more OCBs in return for concerns and helps from colleagues. There are also numerous empirical researches that demonstrate job security is positively related to OCB. For example, research used a multiple-group path analysis of age groups to show that qualitative job insecurity can frustrates people's intrinsically motivated OCB (Stynen, Forrier, Sels \& De Witte, 2013). Ma Liu, Liu and Wang (2015) also demonstrated that job insecurity is negatively related with OCB in the Chinese context (Ma et al., 2015).

The study postulates the following hypotheses to be tested:

Ho : There is no significant relationship between safety and wellbeing and civic virtue in telecommunication companies in Port Harcourt.

Ho5: There is no significant relationship between safety and wellbeing and conscientiousness in telecommunication companies in Port Harcourt.

Ho6: There is no significant relationship between safety and wellbeing and courtesy in telecommunication companies in Port Harcourt

\section{Methodology}

The study adopted a cross-sectional survey research design in its investigation of the variables. Primary data was generated through structured questionnaire. The population of the study was 134 employees drawn from 4 telecommunication companies in Port Harcourt. The sample size was 100 determined through the Taro Yamen formula for sample size determination and the simple random technique was used. After data cleaning, only data of 91 respondents were finally used for data analysis. The reliability of the research instrument was achieved using the Cronbach's Alpha Coefficient. Spearman Rank Order Correlation Coefficient was used to test the hypotheses with the aid of Statistical Package for the Social Sciences. The tests were carried out at the 0.05 level of significance.

\section{Data Analysis And Results \\ Bivariate Analysis}

The Spearman Rank Order Correlation coefficient is calculated using the SPSS 21.0 version to establish the relationship among the empirical referents of the predictor variable and the measures of the criterion variable.

\section{Table 1: Correlation Matrix for Job Security and Organizational Citizenship Behaviour}

\begin{tabular}{|c|c|c|c|c|c|c|}
\hline & & & $\begin{array}{c}\text { Job } \\
\text { security }\end{array}$ & $\begin{array}{l}\text { Civic } \\
\text { virtue }\end{array}$ & $\begin{array}{c}\text { Conscientio } \\
\text { usness }\end{array}$ & $\begin{array}{c}\text { courte } \\
\text { sy }\end{array}$ \\
\hline \multirow{11}{*}{$\begin{array}{l}\text { Spe } \\
\text { arm } \\
\text { an's } \\
\text { rho }\end{array}$} & \multirow[t]{3}{*}{ Job security } & $\begin{array}{l}\text { Correlation } \\
\text { Coefficient }\end{array}$ & 1.000 & $.932^{* *}$ & $.806^{* * *}$ & $.739^{* * *}$ \\
\hline & & Sig. (2-tailed) & & .000 & .000 & .000 \\
\hline & & $\mathrm{N}$ & 150 & 150 & 150 & 150 \\
\hline & \multirow[t]{3}{*}{ Civic virtue } & $\begin{array}{l}\text { Correlation } \\
\text { Coefficient }\end{array}$ & $.932^{* *}$ & 1.000 & $.761^{* * *}$ & $.760^{* * *}$ \\
\hline & & Sig. (2-tailed) & .000 & . & .000 & .000 \\
\hline & & $\mathrm{N}$ & 150 & 150 & 150 & 150 \\
\hline & \multirow[t]{3}{*}{ conscientiousness } & $\begin{array}{l}\text { Correlation } \\
\text { Coefficient }\end{array}$ & $.806^{* * *}$ & $.761^{* *}$ & 1.000 & $.844^{* *}$ \\
\hline & & Sig. (2-tailed) & .000 & .000 & & .000 \\
\hline & & $\mathrm{N}$ & 150 & 150 & 150 & 150 \\
\hline & \multirow[t]{2}{*}{ courtesy } & $\begin{array}{l}\text { Correlation } \\
\text { Coefficient } \\
\end{array}$ & $.739^{* * *}$ & $.760^{* * *}$ & $.844^{* * *}$ & 1.000 \\
\hline & & Sig. (2-tailed) & .000 & .000 & .000 & \\
\hline
\end{tabular}




\begin{tabular}{|l|l|r|r|r|r|}
\hline & $\mathrm{N}$ & 150 & 150 & 150 & 150 \\
\hline$* *$. Correlation is significant at the 0.01 level (2-tailed). \\
\hline
\end{tabular}

\section{Source: SPSS output}

\section{$\mathrm{H}_{01}$ : There is no significant relationship between job security and civic virtue in telecommunication companies in Port Harcourt.}

The correlation coefficient ( $\mathrm{r}$ ) shows that there is a significant and positive relationship between job security and civic virtue. The rho value 0.932 indicates this relationship and it is significant at $\mathrm{p} 0.000<0.05$. The correlation coefficient represents a very strong relationship. Therefore, based on the results, the null hypothesis earlier stated is hereby rejected and the alternate upheld. Thus, there is a significant relationship between job security and civic virtue in telecommunication companies in Port Harcourt.

\section{There is no significant relationship between job security and conscientiousness in telecommunication companies in Port Harcourt.}

The correlation coefficient (r) shows that there is a significant and positive relationship between job security and conscientiousness. The rho value 0.806 indicates this relationship and it is significant at $\mathrm{p} 0.000<0.05$. The correlation coefficient represents a high correlation indicating a strong relationship. Therefore, based on the results, the null hypothesis earlier stated is hereby rejected and the alternate upheld. Thus, there is a significant relationship between job security and conscientiousness in telecommunication companies in Port Harcourt.

Ho $:$ There is no significant relationship between job security and courtesy in telecommunication companies in Port Harcourt.

The correlation coefficient (r) shows that there is a significant and positive relationship between job security and courtesy. The rho value 0.739 indicates this relationship and it is significant at $p 0.000<0.05$. The correlation coefficient represents a strong correlation indicating. Therefore, based on empirical findings the null hypothesis earlier stated is hereby rejected and the alternate upheld. Thus, there is a significant relationship between job security and courtesy in telecommunication companies in Port Harcourt.

\section{Discussion Of Findings}

The test of hypotheses showed that there is a significant relationship between job security and organizational citizenship behaviour in telecommunication companies in Port Harcourt. Hence, the null hypotheses were hereby rejected. This finding agrees with Evren, 2003 who stated that employee's job security is currently even more relevant in economies where jobs are being slashed and hiring new employees has slowed down due to the weak economy. Bull (2005) postulates that many people experience satisfactions when they belief that the future of their job is good and secured. Job security refers to one's expectation about continuity in a job situation (Akpan, 2013). Singh and Jain (2013) define job security as an employee's assurance or confidence that employees will keep their current job. Similarly, Clark and Postel-Vinay (2009); Erlinghagen (2008) refer to job security as a situation where employees perceive the continuance of their employment not to be under any threat. This suggests that, employees will be more comfortable and satisfied when there is no threat of dismissal or lay off of their job in their workplace.

Also, our study corroborates with the findings of Pearce and Mawsons (2009) who opined that Job security is a mind state in which the employee sees his job stability with the firm in the near future. It is the result of the firm's own practices and policies with the employee which make them more secure or insecure towards the job. Employment security as a term is often used interchangeably with work security and job security, job security is the security of a continued employment in the same occupation with the same employer. Conceptually, work security and employment security are broader concepts, including, among other things: self employment, employment security, the confidence of being able to keep, find or create gainful employment, now and in the future, based on the development of your own human capital and in wellfunctioning institutions.(Dekker, 2010). Job security plays an important role in both social and working life because it help individuals not to worry about their future, and it contributes to maintaining labor peace, increasing organizations productivity and protecting social balance and values for this employee should not 
be dismissed from his organization without reasonable grounds, because job security has political and social dimensions (Senol, 2011).

Nazirul, Syeda and Zuby (2014) suggest that job security is one of the major components of job satisfaction in any work place because of its relationship with work behaviours. When a job is not secured an employee tends to look for opportunity elsewhere and that makes him /her less committed and when he/she gets the opportunity, he/she quits easily for a better organization. They also went on to say that employees with a high level of job security have a low probability of losing their job in the near future subsequently becomes a source of employees' job satisfaction. On the contrary, Guest (2004) in his study maintains that low job security and working conditions have adverse effect on employee job satisfaction. However, Abdullah and Ramay (2012) stress that secured job is an employee's requirement and wish. Hence, job insecurity tends to affect workers negatively in their organization (Akpan, 2013). Accordingly, Tannenbaum (1992) reports that developing economies have dare need for job security as a top priority in their work place as it increases employees' job satisfaction and loyalty.

\section{Conclusion And Recommendations}

This study concludes that job security significantly relates with organizational citizenship behaviour in telecommunication companies in Port Harcourt. This implies that when employees feel secured in their job they tend to increases in their organizational citizenship behaviour.

The study recommends that employees who are hard working with the firms should be identified and rewarded for their hard work. Components of job security should be factored into telecommunication companies' job description as it will go a long way in sustaining confidence in the course of discharging their duties. However, this study was able to assess quality of work life and employee turnover and measures by which it can be minimized.

\section{References}

1. Adewale, O.O., Abolaji,A.J. \& Kolade, O.J. (2011). Succession planning and organizational survival: Empirical study on Nigerian private tertiary institutions. Serbian Journal of Management, $6(2), 231-246$.

2. Adewale, O.O., Abolaji,A.J. \& Kolade, O.J. (2011). Succession planning and organizational survival: Empirical study on Nigerian private tertiary institutions. Serbian Journal of Management, $6(2), 231-246$.

3. Adewale, O.O., Abolaji,A.J. \& Kolade, O.J. (2011). Succession planning and organizational survival: Empirical study on Nigerian private tertiary institutions. Serbian Journal of Management, 6(2), 231 - 246.Devinney,

4. T. M., Yip, G. S., \& Johnson, G. 2009. Using frontier analysis to evaluate company performance. British

5. Andaleeb, Q., Javeria, A., Shahjehan, F. Z., \& Kaleem, S. (2011). The effect of self-esteem and organizational identification on organizational citizenship behavior: A case of Pakistani Public Sector University. African Journal of Business Management, 5(9), 3448-3456.

6. Benjamin, O. A. (2015). Impact of organisational culture and leadership style on quality of work-life among employees in Nigeria. African Journal for the Psychological Studies of Social Issues, 18(1), 109-121.

7. Borman, W., Penner, L., Allen, T., \& Motowidlo, S. (2001). Personality predictors of citizenship performance. International Journal of Selection and Assessment.

8. Borman, W.C., Buck, D.E., Hanson, M.A., Motowidlo, S.J., Stark, S., \& Drasgow, F. (2001). An examination of the comparative reliability, validity, and accuracy of performance ratings made using computerized adaptive rating scales. Journal of Applied Psychology, 86, 965-973.

9. Corbin, C. C., \& Lindsey, R. (1994). Concepts of fitness and wellness with laboratories (8th ed). Madison, WI: Brown and Benchmark Publications.

10. Cropanzano, R., \& Mitchell, M.S. (2005). Social exchange theory: An interdisciplinary review. Journal of Management, 31, 874-900. 
11. Cropanzano, R., Rupp, D. E., \& Byrne, Z. S. (2003). The relationship of emotional exhaustion to work attitudes, job performance, and organizational citizenship behaviors. Journal of Applied Psychology, 88(1), 160-169.

12. Devinney, T. M., Yip, G. S., \& Johnson, G. 2009. Using frontier analysis to evaluate company performance. British

13. Devinney, T. M., Yip, G. S., \& Johnson, G. 2009. Using frontier analysis to evaluate company performance. British

14. DeYoung, C. G., Peterson, J. B., \& Higgins, D. M. (2005). Sources of openness/intellect: cognitive and neuropsychological correlates of the fifth factor of personality. Journal of Personality, 73, 825858

15. Eisenberger, R., Stinglhamber, F., Vandenberghe., Sucharski, I. L., \& Rhoades, L. (2002). Perceived supervisor: and employee retention. Journal of Applied Psychology, 87(3), 565-573.

16. Gore, J.S., Kiefner, A.E., \& Combs, K.M. (2012). Personality traits that predict academic citizenship behaviour. Journal of Applied Social Psychology, 42(10), 2433-2456.

17. Hudson, C. (2010). Respect, equity and diversity framework: Creating workplaces with positive cultures.

18. Jiang L., Hub S., Näswallc K., López Bohle S., Wang H.-J. (2020). Why and when cognitive job insecurity relates to affective job insecurity? A three-study exploration of negative rumination and the tendency to negative gossip. European Journal of Work Organ. Psychol. 29 678-692.

19. Journal of Management, forthcoming

20. Journal of Management, forthcoming

21. Journal of Management, forthcoming

22. Kraimer M. L., Wayne S. J., Liden R. C., Sparrowe R. T. (2005). The role of job security in understanding the relationship between employees' perceptions of temporary workers and employees' performance. J. Appl. Psychol. 90 389-398.

23. Lam C. F., Liang J., Ashford S. J., Lee C. (2015). Job insecurity and organizational citizenship behavior: exploring curvilinear and moderated relationships. J. Appl. Psychol. 100 499-510.

24. Lambert, S. J., \& Waxman, E. (2005). Organizational stratification: Distributing opportunities for balancing work and life. In E. E. Kossek \& S. J. Lambert (Eds.), Work and life integration: Organizational, cultural and individual perspectives (103-126). Mahwah, NJ: Erlbaum

25. Law, S. K., Wong, C., \& Chen, X. Z. (2005). The construct of organizational citizenship behavior: Should we analyze after we have conceptualized? In D. L. Turnipseed (Ed.), Handbook of organizational citizenship behavior (47-65). New York: Nova Science Publishers.

26. Ma B., Liu S., Liu D., Wang H. (2015). Job security and work performance in Chinese employees: the mediating role of organisational identification. Int. J. Psychol. 51 123-129.

27. Okediji, A.A., Esin, P.A., Sanni, K.B., \& Umoh, O.O. (2009). The influence of personality characteristics and gender on organisational citizenship behaviour. Global Journal of Social Sciences, 8 (2), 69-76.

28. Onyishi, I.E. (2007). Development and validation of organizational citizenship behaviour scale in Nigeria. ESUT Journal of Psychological Studies, 2(1), 55-78.

29. Organ, D. W. (1988). Organizational citizenship behavior: Its nature, antecedents and consequences. New York: Saga Publications.

30. Organ, D. W. (1990b). The subtle significance of job satisfaction. Clinical Laboratory Management Review, 4, 94-98.

31. Organ, D. W., Podsakoff, P. M., \& MacKenzie, S. B. (2006). Organizational citizenship behavior: Its nature, antecedents, and consequences. London: Sage Publications.

32. Piccoli B., De Witte H., Reisel W. D. (2017). Job insecurity and discretionary behaviors: social exchange perspective versus group value model. Scand. J. Psychol. 58 69-79.

33. Podsakoff, P. M., Mackenzie, S. B., Paine, J. B., \& Bachrach, D. G (2000). Organizational citizenship behaviours: A critical review of the theoretical and empirical literature and suggestions for future research. Journal of Management, 26, 513-563.

34. Rezaeian, A. (2005). Organizational behavior basics, 6th edition. Tehran: Samt Publication.

35. Rhoades, L., \& Eisenberger, R. (2002). Perceived organizational support: A review of the literature. Journal of Applied Psychology, 87(4), 698-714. 
36. Robbins, S. F., \& Judge, T. (2009). Organizational behavior, 13th edition (Pearson Education, Inc, Prentice-Hall Inc)

37. Robbins, S.F. \& Judge, T.A. (2007). Organizational behaviour, 12th Edition. New York: Pearson Education Inc., 551-557.

38. Stynen D., Forrier A., Sels L., De Witte H. (2013). The relationship between qualitative job insecurity and OCB: differences across age groups. Econ. Industr. Democr. 36 383-405.

39. Stynen, D., Forrier A., Sels, L., De Witte, H. (2013). The relationship between qualitative job insecurity and OCB: differences across age groups. Econ. Industr. Democr. 36 383-405.

40. Uhiara, A.C., Njoku, J.C., Ngozi, A.S., \& Jimogu, S.C. (2011). The relationship between organisational justice and organisational citizenship behaviour in a small Nigerian sample. Journal of Research and Development, 3(1), 133-138.

41. Vuuren T. V., Jong J. P. D., \& Smulders, P. G. W. (2020). The association between subjective job insecurity and job performance across different employment groups. Career Development, Int. 25 229-246.

42. Wright, P. M., \& McMahan, G. C. (2011). Human resources and sustained competitive advantage: A resource-based perspective. International Journal of Human Resource Management, 5, 301-326. 